\title{
Integrated modelling in coastal lagoons: Sacca di Goro case study
}

\author{
D. Marinov · J. M. Zaldívar · A. Norro • \\ G. Giordani · P. Viaroli
}

(C) The Author(s) 2008

\begin{abstract}
A coupled 3D hydrodynamic-biogeochemical model was developed and implemented for the Sacca di Goro coastal lagoon. The model considers nutrient and oxygen dynamics in water column and sediments. Among the biological elements, phytoplankton, zooplankton, bacteria, Ulva sp. and commercial shellfish (Tapes philippinarum) were taken into consideration. Nutrients fluxes from the watershed and open sea, as well as atmospheric inputs, heat flux, light intensity and wind shear stress at the water surface constituted the model forcing functions.
\end{abstract}

Guest editors: A. Razinkovas, Z. R. Gasiūnaitè, J. M. Zaldívar \& P. Viaroli

European Lagoons and their Watersheds: Function and Biodiversity

\section{Marinoy}

European Commission, Joint Research Centre, Institute for Environment and Sustainability, Ispra, VA, Italy

Present Address:

J. M. Zaldívar $(\square)$

European Commission, Joint Research Centre, Institute for Health and Consumer Protection, Ispra, VA, Italy e-mail: jose.zaldivar-comenges@jrc.it

\section{A. Norro}

Management Unit of the North Sea Mathematical Models, Royal Belgian Institute for Natural Sciences, Brussels, Belgium

G. Giordani · P. Viaroli

Department of Environmental Sciences, Parma

University, Parma, Italy
The comparison of numerical results with available measurement data indicated that the model was able to capture the essential dynamics of the lagoon. This model has also been used to estimate clam productivity and its impacts on water quality and lagoon properties.

Keywords 3D numerical coupled-model .

Nutrients transport - Oxygen - Clam production . Macroalgal blooms $\cdot$ Anoxic crises

\section{Introduction}

Transitional waters and coastal zones are very heterogeneous complex systems with different characteristics, which react in different ways to the nutrient and organic matter loadings from watersheds, as well as to global changes (Crossland et al., 2005; Eisenreich, 2005). Among these, coastal lagoons are subjected to strong anthropogenic pressures, as they receive nutrients and pollutants as well as they are heavily exploited for aquaculture and tourism.

Coastal lagoons are highly dynamic due to the balance between solid transport and deposition, and coastal erosion. The rapid accretion and erosion of littoral arrows and sand barriers determine deep modification of hydrodynamics and, as a consequence, of communities (Kjerfve, 1994). The large availability of inorganic and organic nutrients and light support a great primary production of species adapted to the wide range of geomorphological, physical and chemical conditions with a dominance 
of phanerogams in the pristine conditions (Borum, 1996; Hemminga, 1998; De Wit et al., 2001). An increasing nutrient input is thought to favour in a first phase phytoplankton and epiphytic microalgae, and later floating ephemeral macroalgae, cyanobacteria and/or picoplankton species. These changes have been particularly severe in the Mediterranean coastal lagoons, with summer events of anoxia and frequent dystrophy (Castel et al., 1996; Schramm \& Nienhuis, 1996; Hemminga, 1998). Mediterranean coastal lagoons are generally shallow, micrototidal or non tidal. Due to the high sediment surface area to water volume ratios, processes occurring within the sediment and at the water-sediment interface strongly influence ecosystem metabolism and nutrient budgets (Castel et al., 1996). Overall, community and ecosystem dynamics are for the most part unpredictable and subjected to a marked variability at both spatial and temporal scales. Therefore, studies of structure, processes and functions of such complex ecosystems can be performed only with quantitative model tools.

The Sacca di Goro (SG) lagoon is an important environmental and economical site in the Po River Delta. Here, clams, and to a some extent mussels, farming provide local employment for more than 1,000 people and result in annual economical revenue oscillating during last decade around 50 million Euros (Viaroli et al., 2006). The eastern part of SG was included in the Regional Natural Park of the Po River delta and was assessed as an area rich of a wide variety of habitats and biota which are of national and international interest and under protection of RAMSAR convention, UNESCO heritage sites and Site of Interest of European Community.

SG has a triangular shape, maximum length of $11 \mathrm{~km}$, maximum width of $5 \mathrm{~km}$, with a surface area of $26 \mathrm{~km}^{2}$, an average depth about $1.5 \mathrm{~m}$, a volume of approximately 39 millions $\mathrm{m}^{3}$ and a time variable bathymetry and boundaries (O'Kane et al., 1992; Simeoni et al., 2000; Viaroli et al., 2006). The basic hydrodynamic forcing on SG is linked with the tidal dynamics of Adriatic Sea (AS), since the lagoon is connected with the adjacent sea by two mouths which at present are of equivalent sizes of about $900 \mathrm{~m}$. Tidal amplitudes in SG vary up to $0.9 \mathrm{~m}$. The freshwater inputs to SG are mainly from Po di Volano (PV) (about 350 millions $\mathrm{m}^{3} \mathrm{y}^{-1}$ ) and Po di Goro (PG), at least until 1994 when the PG discharge was considerably reduced because it started to be human- regulated by sluices (Bencivelli, 1998). In addition, three canals of similar importance (Giralda, Bonello and Canal Bianco) delivered 20-55 millions $\mathrm{m}^{3} \mathrm{y}^{-1}$ each to SG. Precipitation has an annual value between 500 and $600 \mathrm{~mm}$ that does not affect considerably the SG water balance. Previous investigations on SG hydrodynamics indicated that the lagoon can be partitioned into three zones (Marinov et al., 2006; Viaroli et al., 2006). The central part not only is mainly dominated by the AS but is also considerably influenced by the freshwater delivered from PV and minor canals. For these reasons fast changes and high oscillations in temperature and salinity occurred. The western part is under the influence of the PV plume, which leads to a lowersalinity and wider-salinity fluctuations. In the eastern part of SG, which is shallow, sheltered and affected by freshwater inflows from PG, a relatively low salinity is also accompanied by higher temperatures. The mean residence time is approximately 1 day in the western zone, 3-6 days in the central area and 20-25 days in the easternmost part of SG (Marinov et al., 2006).

In the last decades, SG was exposed to high anthropogenic nutrients load, approximately $2,000 \mathrm{t} \mathrm{y}^{-1}$ of $\mathrm{N}$ and $60 \mathrm{ty}^{-1}$ of $\mathrm{P}$, which caused severe eutrophication processes (Viaroli et al., 2001, 2006). From 1987 to 1997, persistent blooms of the seaweeds Ulva sp. and, to a lesser extent, of Gracilaria sp. and Cladophora sp. occurred especially in the easternmost shallow area, whilst phytoplankton blooms prevailed in the deeper central zone. The accumulation of up to 50-70,000 tons of wet macroalgal biomass in late spring supported a strong oxygen consumption which led to complete anoxia and dystrophic crises in almost half of the lagoon (Viaroli et al., 2001, 2006). Since about onethird of the lagoon was exploited for clam, the persistent summer anoxia caused crop losses with significant economical damages to the local community. In August 1992, after a particularly severe anoxic crisis, a 300-400 wide and ca. $2 \mathrm{~m}$ deep artificial channel was cut through the sand barrier which separates SG from AS, aiming to improve water renewal. The hydrodynamic modelling results (Marinov et al., 2006) showed that the new connection led to the formation of additional vortex structures inside the central part of the lagoon which reduced the current speed in the main strait and 
enlarge the eddy circulation in the central and eastern parts of SG. Consequently, water temperatures increased in winter and decreased during the rest of the year, with an average variation of salinity and temperature ranging from $10 \%$ to $20 \%$. Although the hydrodynamic modelling is able to support several management objectives, the nutrient biogeochemistry and ecology of SG-including clam aquaculturewere not taken into account. Therefore, to address all these aspects, the simulation tools were extended to consider ecological compartments.

This work aims at developing and implementing an integrated/coupled 3D hydrodynamic-biogeochemical model for the Sacca di Goro lagoon. The coupled model is designed by integration of previously established models, namely COHERENS (Luyten et al., 1999, 2003) a 3D hydrodynamic finite-difference multi-purpose model, a 0D biogeochemical model (Zaldívar et al., 2003) and a stagebased model for clam farming activities including seeding and harvesting (Zaldívar et al., 2005). The resulting 3D hydrodynamic-biogeochemical model accounts the specific physical and biological processes of the lagoon and address both water column and sediments. The nutrients, phytoplankton, zooplankton, bacteria and Ulva dynamics, as well as shellfish farming, are taken into consideration. Due to the frequent anoxic crises in coastal lagoons, special emphasis is then dedicated to the simulation of oxygen dynamics. The nutrients fluxes from the watershed and open sea as well as atmospheric inputs, heat flux, light intensity and wind shear stress at the water surface constitute the model forcing functions. This application is also intended as a tool for performing the analysis of possible alternative scenarios (Marinov et al., 2007) and as a complement in the products distribution study of plant protection (Carafa et al., 2006).

\section{Materials and methods}

\section{Biogeochemical model description}

The different components of the 3D hydrodynamicbiogeochemical model have been discussed in detail by Marinov et al. (2006) for hydrodynamics, Zaldívar et al. (2003) for ecology and biogeochemistry, and by Zaldívar et al. (2005) for the stage-based model of clam farming. Here, we will focus on the results obtained by the integration of all these compartments, using approach and assumptions of the above-mentioned works.

The model enhancement was technically carried out by modification of the OD model equations, which primarily consist of time derivatives and source/sink terms, by adding a complete set of advectiondiffusion dynamical terms to each of original $0 \mathrm{D}$ model equations by Zaldívar et al. (2003). Since the model extension is built on the original 38 state variables of $0 D$ version here they are only summarized in Table 1. Among these, five were for nutrients in the water column and five in the sediments; organic matter was represented by sixteen state variables in the water column and two in the sediments; the ten biological variables composed of six for phytoplankton, two for zooplankton, one for bacteria and one for Ulva sp.; six variables were used for the stage-based discrete model for clams.

Similarly to the previous solely hydrodynamic application for SG (Marinov et al., 2006) the horizontal grid space resolution was kept to $150 \mathrm{~m}$ $(73 \times 46$ grid cells) and since SG is a shallow water body only three layers in the $\sigma$-transformed vertical space have been used.

Total dissolved nitrogen (nitrates, nitrites and ammonium) and dissolved reactive phosphorous were included as the main nutrients which limit phytoplankton growth (Pugnetti et al., 1992). Due to the shallow depth and the relative importance of the benthic component, sedimentary fluxes were also taken into account. Dissolved Reactive Silica (DRSi) was introduced in order to consider the diatom component separately from flagellates (Tusseau et al., 1997, 1998). Finally, oxygen dynamic was used to study the evolution of hypoxia and the anoxic events that have occurred in the SG.

The phytoplankton module was based on the AQUAPHY model (Lancelot et al., 1991) and explicitly distinguished between photosynthesis (directly dependent on irradiance) and phytoplankton growth (dependent on both nutrient and energy availability). Each phytoplankton community was described by three state variables defined according to their metabolic function: the monomers, the reserve products, and the functional and structural macromolecules (Tusseau et al., 1997; Lancelot et al., 2002). 
Table 1 State variables and units used in the biogeochemical model
DOC: Dissolved organic carbon; DON: dissolved organic nitrogen; DOP: dissolved organic phosphorus; POC: particulate organic carbon; PON: particulate organic nitrogen; POP: particulate organic phosphorus; pw: pore water; dw: dry weight

\begin{tabular}{|c|c|c|c|}
\hline Variable & Unit & Variable & Unit \\
\hline Water column & & Water column & \\
\hline Nitrate & $\mathrm{mmol} \mathrm{m}^{-3}$ & Diatoms & $\mathrm{mg} \mathrm{C} \mathrm{m}^{-3}$ \\
\hline Ammonium & $\mathrm{mmol} \mathrm{m}^{-3}$ & Flagellates & $\mathrm{mg} \mathrm{C} \mathrm{m}^{-3}$ \\
\hline Reactive phosphorous & $\mathrm{mmol} \mathrm{m}^{-3}$ & Micro-zooplankton $(40-200 \mu \mathrm{m})$ & $\mathrm{mg} \mathrm{C} \mathrm{m}{ }^{-3}$ \\
\hline Dissolved reactive silica & $\mathrm{mmol} \mathrm{m}^{-3}$ & Meso-zooplankton $(>200 \mu \mathrm{m})$ & $\mathrm{mg} \mathrm{C} \mathrm{m} \mathrm{m}^{-3}$ \\
\hline Dissolved oxygen & $\mathrm{g} \mathrm{m}^{-3}$ & Bacteria & $\mathrm{mg} \mathrm{C} \mathrm{m}{ }^{-3}$ \\
\hline Monomeric DOC & $\mathrm{mg} \mathrm{C} \mathrm{m}{ }^{-3}$ & Ulva (as dry weight) & $\mathrm{kg} \mathrm{m}^{-3}$ \\
\hline Monomeric DON & $\mathrm{mmol} \mathrm{m}^{-3}$ & $\mathrm{~N}$ in Ulva tissue (dry weight) & $\mathrm{mg} \mathrm{N} \mathrm{g}^{-1}$ \\
\hline Detrital biogenic silica & $\mathrm{mmol} \mathrm{m}^{-3}$ & Sediments & \\
\hline High biodegradability & & Ammonium (pw) & $\mathrm{mmol} \mathrm{m}^{-3}$ \\
\hline DOC & $\mathrm{mg} \mathrm{C} \mathrm{m} \mathrm{m}^{-3}$ & Nitrate (pw) & $\mathrm{mmol} \mathrm{m} \mathrm{m}^{-3}$ \\
\hline DON and DOP & $\mathrm{mmol} \mathrm{m}^{-3}$ & Phosphorous (pw) & $\mathrm{mmol} \mathrm{m} \mathrm{m}^{-3}$ \\
\hline POC & $\mathrm{mg} \mathrm{C} \mathrm{m}{ }^{-3}$ & Dissolved oxygen (pw) & $\mathrm{g} \mathrm{O}_{2} / \mathrm{m}^{3}$ \\
\hline PON and POP & $\mathrm{mmol} \mathrm{m}^{-3}$ & Inorganic adsorbed $\mathrm{P}(\mathrm{dw})$ & $\mu \mathrm{g} \mathrm{g}^{-1}$ \\
\hline Low biodegradability & & PON (dw) & $\mu \mathrm{g} \mathrm{g}^{-1}$ \\
\hline DOC & $\mathrm{mg} \mathrm{C} \mathrm{m}{ }^{-3}$ & POP $(d w)$ & $\mu \mathrm{g} \mathrm{g}^{-1}$ \\
\hline DON and DOP & $\mathrm{mmol} \mathrm{m}^{-3}$ & & \\
\hline POC & $\mathrm{mg} \mathrm{C} \mathrm{m}{ }^{-3}$ & & \\
\hline PON and POP & $\mathrm{mmol} \mathrm{m}^{-3}$ & & \\
\hline
\end{tabular}

The zooplankton module considered micro- and meso-zooplankton compartments (Lancelot et al., 2002). Feeding mechanisms of copepods and microzooplankton were described by Monod-type kinetics with saturation of the specific ingestion rate at high food concentrations.

The Ulva module was adapted from Solidoro et al. (1997a, b). The variation of Ulva biomass was expressed as the specific rates of biomass growth and losses, whereas the rate of mortality composed of two terms. The first represented the intrinsic mortality whilst the second was a function of the difference between the oxygen demand and the availability of dissolved oxygen.

The organic matter degradation module was based on the version of Lancelot et al. (2002) of the microbial loop model developed by Billen (1991). In this model, all microorganisms undergo autolytic processes which release in the water column dissolved and particulate polymeric organic matter, each with two classes of biodegradability. The detritus particulate organic matter undergoes sedimentation. In order to consider Ulva sp. decomposition a few specific terms were added to the original model. Ulva decomposition was given by the death biomass multiplied by the corresponding parameter depending on the element $(\mathrm{C}, \mathrm{N}$, or $\mathrm{P})$ considered. In the case of $\mathrm{N}$, the nitrogen content of Ulva was used in the calculation instead of a constant factor. Then this quantity was divided among the different model compartments using data from Viaroli et al. (1992). From these data, $58 \%$ of the total phosphorous from Ulva decomposition was released as soluble reactive phosphorous, whereas the rest was partitioned between organic dissolved and particulate forms. Furthermore, it was assumed that the nitrogen compounds are released mostly as DON and PON, whilst the nitrate and ammonium quota is less than $5 \%$.

In shallow lagoons the sediment act as sinks of organic detritus and consume oxygen due to bacterial mineralization, oxidation processes and benthic fauna respiration (Bartoli et al., 1996, 2001a). Furthermore, particulate matter undergoes mineralization and through resuspension or diffusion reaches the water column. The sediment equations have been adapted from Chapelle (1995).

The module of Tapes philippinarum was based on the continuous growth model of Solidoro et al. (2000) that was transformed into variable stage duration for each class in the discrete stage-based model. Filtration, ingestion, assimilation and 
respiration rates were calculated as functions of the number of individuals, body size (as dry weight), mean temperature and food quantity. These values were then introduced into the corresponding mass balances equations of the model. The shellfish farming is implicitly taken into account through their biomass as a forcing function. Data on clam biomass were obtained from Ceccherelli et al. (1994) and Bencivelli (private communication) and were introduced in the model assuming that shellfish farming took place during the whole year (Ceccherelli et al., 1994; Melià et al., 2003).

\section{Model forcing}

Nutrient fluxes from the watershed and wet and dry deposition, heat fluxes, photosynthetic active radiation, wind speed and shellfish production were considered as biogeochemical model forcing functions. Physical forcing, namely wind, air temperature, air humidity, clouds covering, precipitation, AS tides, river and canal discharges, water temperature and salinity in AS connections and freshwater inlets were described by Marinov et al. (2006).

Monitoring data on nutrients (nitrates plus nitrites, ammonium, total phosphorous and DRSi) and oxygen loadings were considered for the main freshwater sources. Total phosphorous was partitioned into dissolved $(36 \%)$ and particulate $(64 \%)$ fractions following Viaroli et al. (2006).

The exchanges between SG and AS were estimated taking into account historical data of AS Station 3 which is in front of the SG. Oxygen, dissolved inorganic nitrogen (DIN), phosphate, total phosphorous (TP), total nitrogen (TN) and chlorophyll- $a$ data of Station 3 were kindly provided by ARPA Emilia Romagna. TP, TN and chlorophyll- $a$ were divided into several model compartments. TP was partitioned as for watershed sources. The difference between TN and DIN was assumed as $80 \%$ DON and $20 \%$ PON, both with different degrees of biodegradability. The chlorophyll- $a$ concentrations were converted into model boundary conditions for plankton groups of diatoms (DAF) and flagellates (FLF) according to their optimal growth temperatures and the relationship chl $=(\mathrm{DAF}+\mathrm{FLF}) / 40$ (Tusseau et al., 1998).

Total irradiance was used to compute photosynthetic rates; wind speed was used to calculate the oxygen mass transfer rate between the atmosphere and the water column, and precipitation was considered as a term that affects the atmospheric input of nutrients to the SG.

The nutrient fluxes through atmospheric wet and dry deposition were also been considered following the procedure as described by Arhonditis et al. (2000). The estimation of these fluxes was based on existing literature for the Mediterranean (Herut \& Krom, 1996; Medinets, 1996) and on local precipitation data from the meteorological station of PV for the period 1989-1998. An average rainfall composition of $31.1\left[\mathrm{NO}_{3}{ }^{-}\right], 16.7\left[\mathrm{NH}_{4}{ }^{+}\right] 0.48\left[\mathrm{PO}_{4}{ }^{3-}\right], 1.3$ $\left[\mathrm{Si}(\mathrm{OH})_{4}\right] \mathrm{mmol} \mathrm{m}^{-3}$ was used to calculate nutrient fluxes (Herut \& Krom, 1996). The annual dry deposition of $110 \quad\left[\mathrm{NO}_{3}{ }^{-}\right], 275 \quad\left[\mathrm{NH}_{4}{ }^{+}\right], \quad 13.9$ $\left[\mathrm{PO}_{4}{ }^{3-}\right] \mathrm{kg} \mathrm{km}^{-2} \mathrm{y}^{-1}$ was also used (Medinets, 1996). Whilst the influence of atmospheric nutrient fluxes was practically negligible in comparison with freshwater and marine sources, the air-water oxygen exchange was quantitatively important.

\section{Initial conditions}

The initial conditions for model variables were obtained by interpolation of experimental data, whereas equilibrium was assumed between the water column and the interstitial water. This approach accounts for all nutrients state variables. The other variables were initialized using results from the $0 \mathrm{D}$ model of Zaldívar et al. (2003) that was run from 1989 to 1998. The data for clam population were initialized using results from the discrete OD stagebased model of Zaldívar et al. (2005). The model simulations covered the entire 1992 and started from homogeneously spatial distributed quantities (after a short transient phase the model quickly adjusted to relevant heterogeneous conditions) for all the considered state variables except for Ulva sp.

The initial Ulva sp. distribution followed the findings that in winter macroalgal colonies survive only in sheltered, shallow and low current zones of lagoons (Solidoro et al., 1997a, b) as well as observations of Ulva sp. seasonal dynamics in SG (Viaroli et al., 2006). For these reason simulations were started with two Ulva sp. patches placed around point 33 inside the SG (Fig. 1). The spot has surface area ca. 54 ha and the Ulva density was assumed to be about $60-100 \mathrm{~g} \mathrm{~m}^{-2}$ as dry weight. 


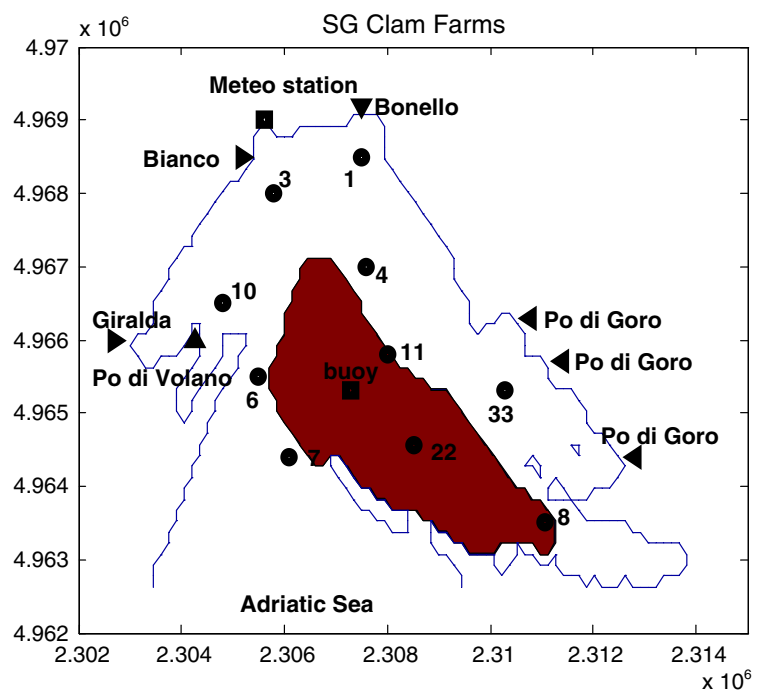

Fig. 1 A general view of Sacca di Goro coastal lagoon, connection with sea-mouths, rivers and canal inlets, sampling stations (marked with numbers) and area of lagoon exploited for clam (Tapes philippinarum) farming (dark area, 882 ha) in 1992

The total area devoted to clam farming was 886.5 ha, corresponding to 394 computational cells of size $150 \times 150 \mathrm{~m}$ each. The spatial clam farms distribution is illustrated in Fig. 1. The clam distribution within farms was assumed initially homogeneous. According to previous study we considered two seeding periods (Castaldelli et al., 2003; Vincenzi et al., 2006). The first seeding was performed from 1st to 31st March, whilst the second was from 15th October to 15th November. We assumed that the seeding rate was constant over the two periods and that the number of seeding individuals corresponded to 1,000 ind $\mathrm{m}^{-2} \mathrm{~d}^{-1}$. This number of individuals was added to Class 1 every day during the seeding periods. A constant harvesting rate was then adopted during all time of the year (Ceccherelli et al., 1994). On average, 90\% of clams of Class 6 and $40 \%$ of clams of Class 5 were harvested every time, the harvested clams being of marketable sizes 'medium' (37 mm) and 'large' (40 mm) according to Solidoro et al. (2000).

\section{Results}

Two model runs were carried out for 1992, with and without clams. The comparison with experimental values, however, was performed only with the complete model including clams. Both runs took into account the change of lagoon boundaries and bathymetry in August 1992, when a 300-400 m wide and ca. $2 \mathrm{~m}$ deep channel was cut through the sand bank aiming at increasing the lagoon hydrodynamics. The complete study of SG hydrodynamics was discussed elsewhere (Marinov et al., 2006).

Nutrients and oxygen dynamics

Experimental and simulated nutrient dynamics are shown in Fig. 2 for the central part of SG. A typical seasonal trend, especially for nitrates and ammonium, was evidenced with an increase in autumn and winter and the subsequent depletion in spring and summer. Simulated and experimental results were in good agreement. Similar results were also obtained at different stations in the lagoon (results not shown).

Spatial distributions of nutrient in SG are presented in Fig. 3 for August. The influence of the watershed can be observed, especially concerning reactive phosphorus. As Burana-Po di Volano watershed was man-regulated, flows from channels did not follow the typical Mediterranean pattern. The maximum concentrations were observed in the plume area of PV, Giralda and Canal Bianco in the western zone of SG, in front of the Bonello canal inlet and in the eastern zone, which was under the influence of PG. In the eastern sheltered zone of the lagoon nitrate and phosphate concentrations were high through the year leading to conditions which in combination with the slow water renewal favoured the macroalgal blooms and subsequent dystrophy, as was experimentally observed by Viaroli et al. (2001, 2006). In the southern part of the lagoon, along the sand barrier and within the clam farming area, relatively high concentrations of ammonium were found, which probably depend on clam metabolism, since the model considers the findings of Bartoli et al. (2001b) concerning ammonium production by clams.

The simulation of oxygen trends in the central part of the lagoon was in good agreement with the experimental data determined monthly in 1992 (Fig. 4). The supersaturation conditions detected in spring coincided to a large extent with the development of Ulva in SG (Viaroli et al., 1993). The spatial distribution of oxygen in the water column and pore water (Fig. 5) evidenced the lagoon zonation, with 
Fig. 2 Measured and simulated nutrient concentrations in the central zone of the Sacca di Goro (SG) lagoon
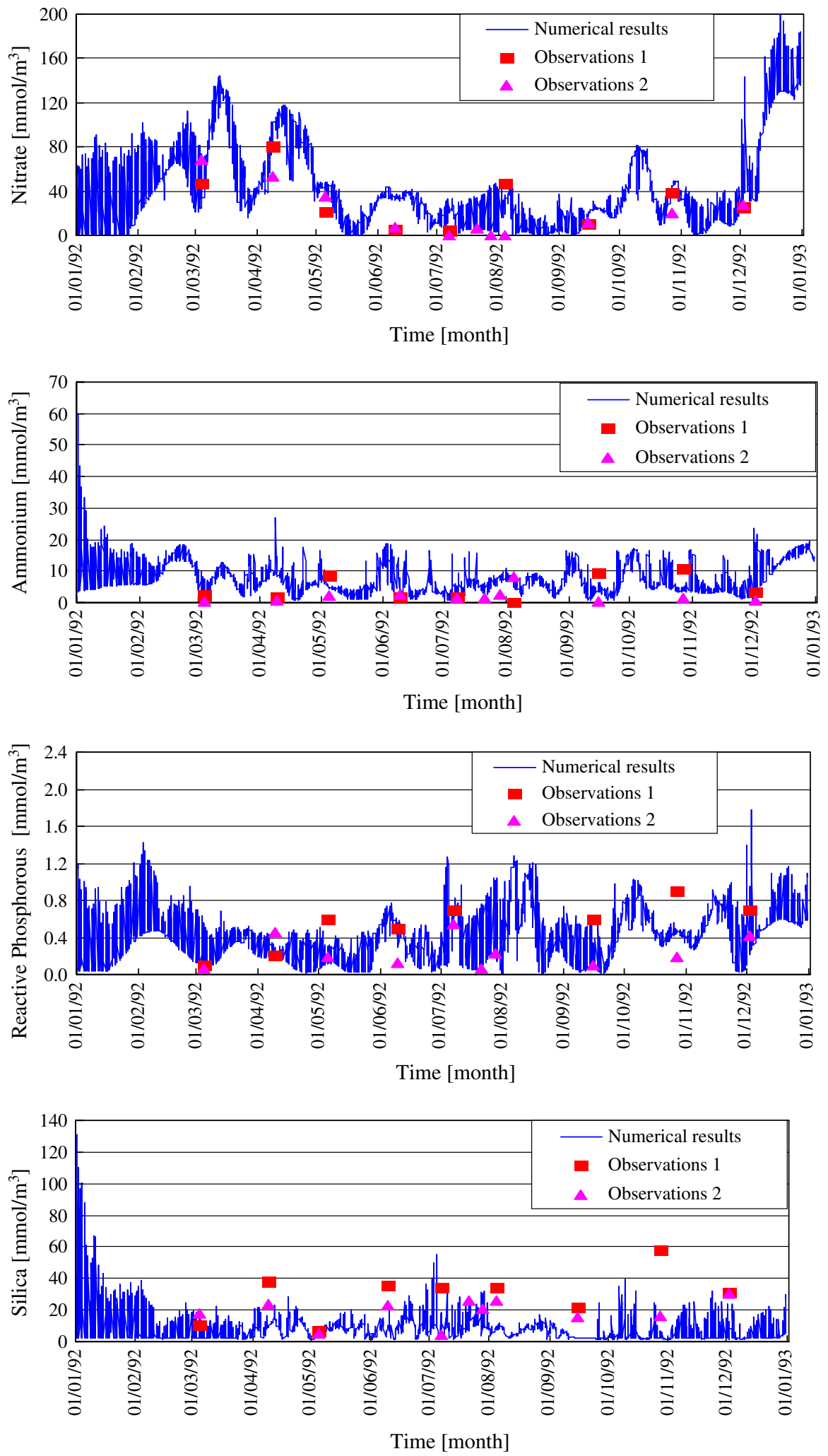

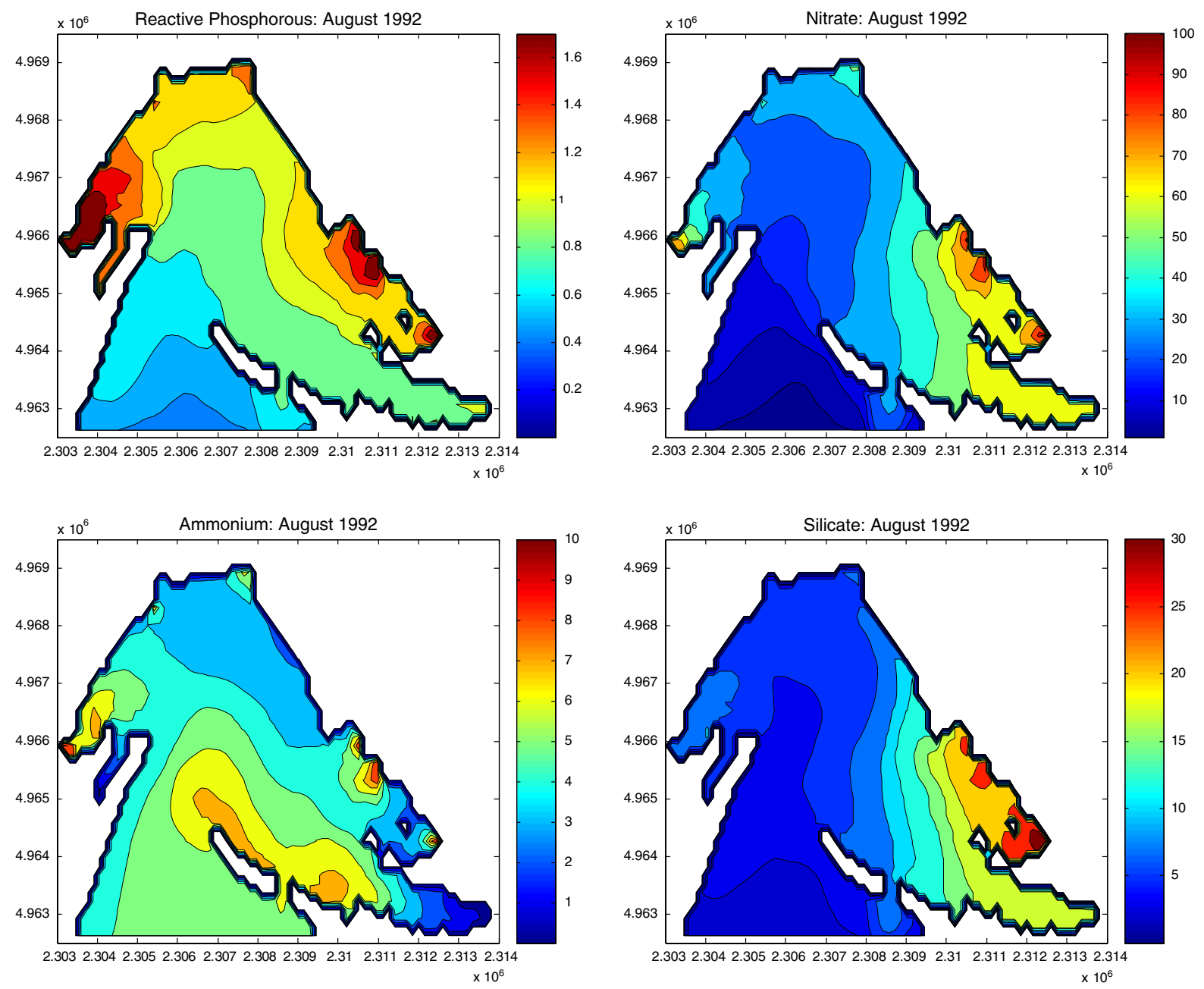

Fig. 3 Spatial surface distribution in August 1992 of soluble reactive phosphorus, nitrates, ammonium and dissolved reactive silica $\left(\mathrm{mmol} \mathrm{m} \mathrm{m}^{-3}\right)$ in SG for model run with clams

Fig. 4 Temporal evolution of dissolved oxygen in the central part of SG

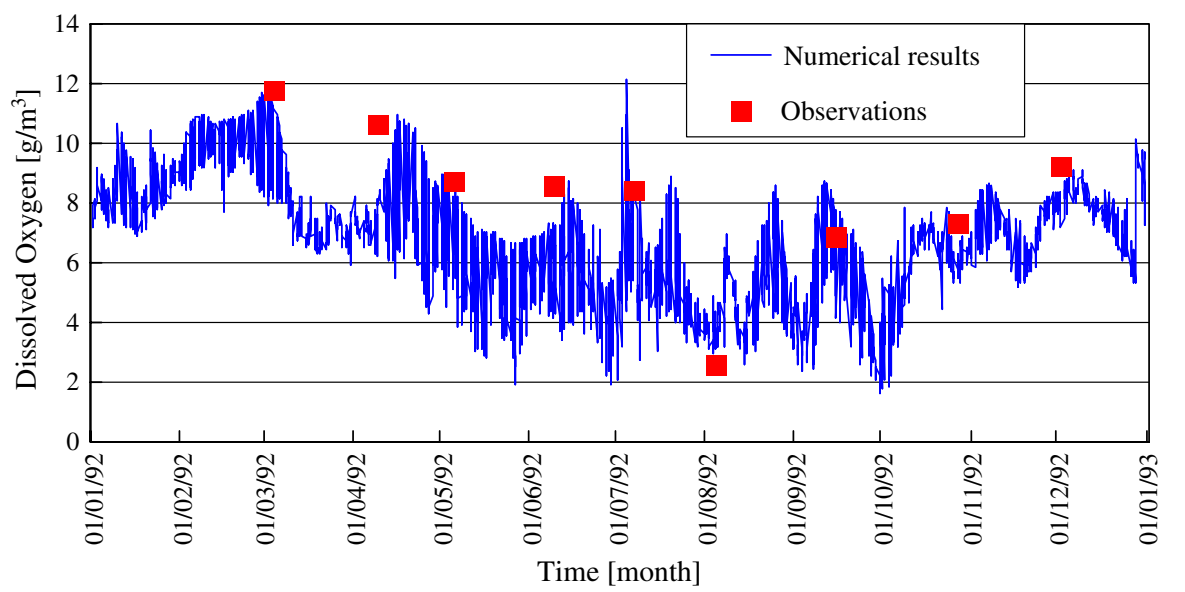



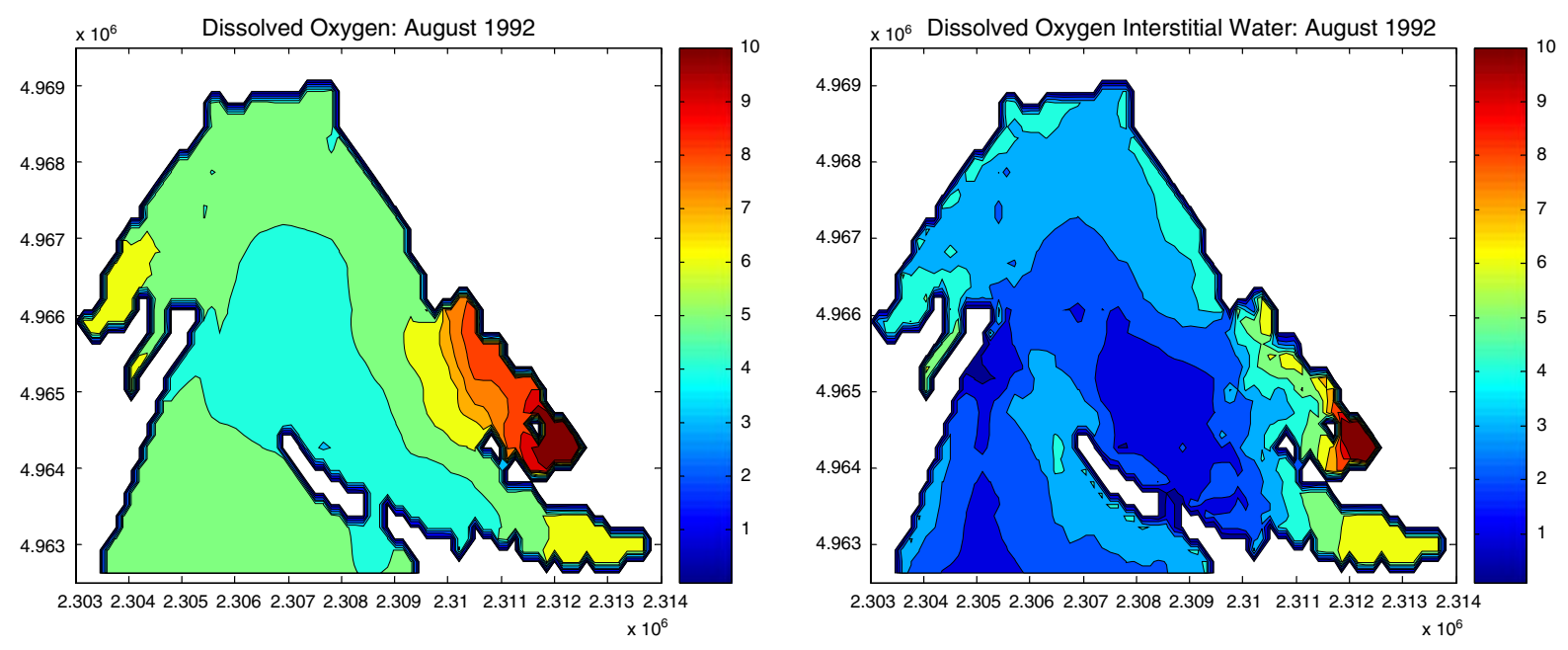

Fig. 5 Spatial distribution of dissolved oxygen $\left(\mathrm{g} \mathrm{m}^{-3}\right)$ in the water column and in the interstitial water in August 1992

the lowest concentrations in the Southeastern zone influenced by Ulva and in the farming area as well.

Organic matter and microbial loop

The experimental and simulated values are shown in Fig. 6 for DON, PON, TDP and TPP (see also Table 1 for acronyms and symbols). Unfortunately, the forcing values for some of these variables were missing, and therefore, high deviations between experimental and simulated values were obtained. For example, the model took into account only organic fraction of dissolved phosphorous which explains why there is a satisfactory agreement between experimental and simulated results for TDP, whilst predicted values were lower than observed concentrations of TPP (Fig. 6).

The development of bacterial communities was only simulated with the model, since only few data were collected, concerning pathogen bacteria (Bucci et al., 1994). Counts and biomass of bacteria were not determined in SG, and therefore, a direct comparison with simulated data is not possible. Bacterial biomass is presented in Fig. 7 where the direct and indirect effects of clam farming on SG ecosystem are shown.

The spatial distribution of dissolved and particulate $\mathrm{P}$ and $\mathrm{N}$ is provided for August 1992 only for the case with cultivation of clams (Fig. 8). An indirect validation of the model runs can be inferred from
TPP data, which peaked in the plume area of PV and in the outlets of PG, suspended particulate matter being responsible of $\mathrm{P}$ adsorption and transport in the Po River (Provini \& Binelli, 2006). The riverine influence was also evident for TDP, although high concentrations were found in the muddy areas. By contrast, PON was mostly affected by AS, whilst DON peaked in the easternmost zone of SG, where macroalgal bloom developed.

\section{Phytoplankton and zooplankton}

Seasonal trends of phytoplankton were simulated as chlorophyll- $a$ concentrations, the chlorophyll- $a$ being used as a proxy of phytoplankton biomass (Fig. 9). The model simulation conformed, to an acceptable extent, with the measured concentrations of chlorophyll-a. Summer peaks, which followed the macroalgal crash, were captured by the model, whilst we observed some discrepancies between simulated and measured data in late summer and autumn. Whilst the summer peak of phytoplankton was detected several times, phytoplankton blooms in autumn were relatively rare (Pugnetti et al., 1992; Viaroli et al., 1992). The summer peak was explained as a consequence of phytoplankton enrichment from the AS which was internally supported by the inorganic nutrient recycling from decomposing Ulva biomasses (Viaroli et al., 1992), whereas the autumn phytoplankton bloom was suppressed by the 
Fig. 6 Comparison of numerical results and measured concentrations of dissolved (DON) and particulate $(\mathrm{PON})$ organic nitrogen, and total dissolved (TDP) and particulate (TPP) phosphorus in the central part of SG
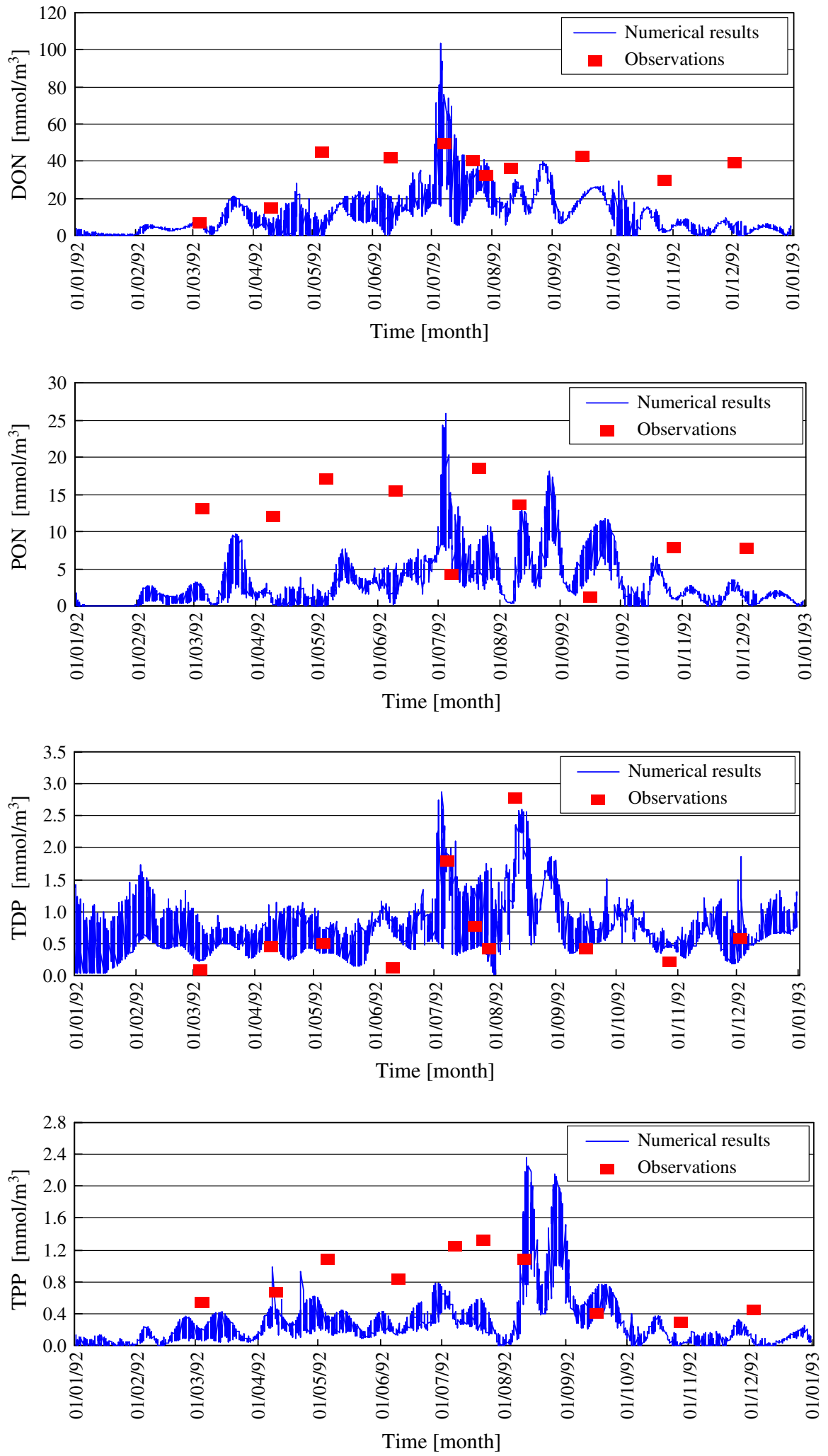
Fig. 7 Numerical results for zooplankton and bacteria $\left(\mathrm{mg} \mathrm{C} \mathrm{m}^{-3}\right)$ at the buoy station in SG with and without clams
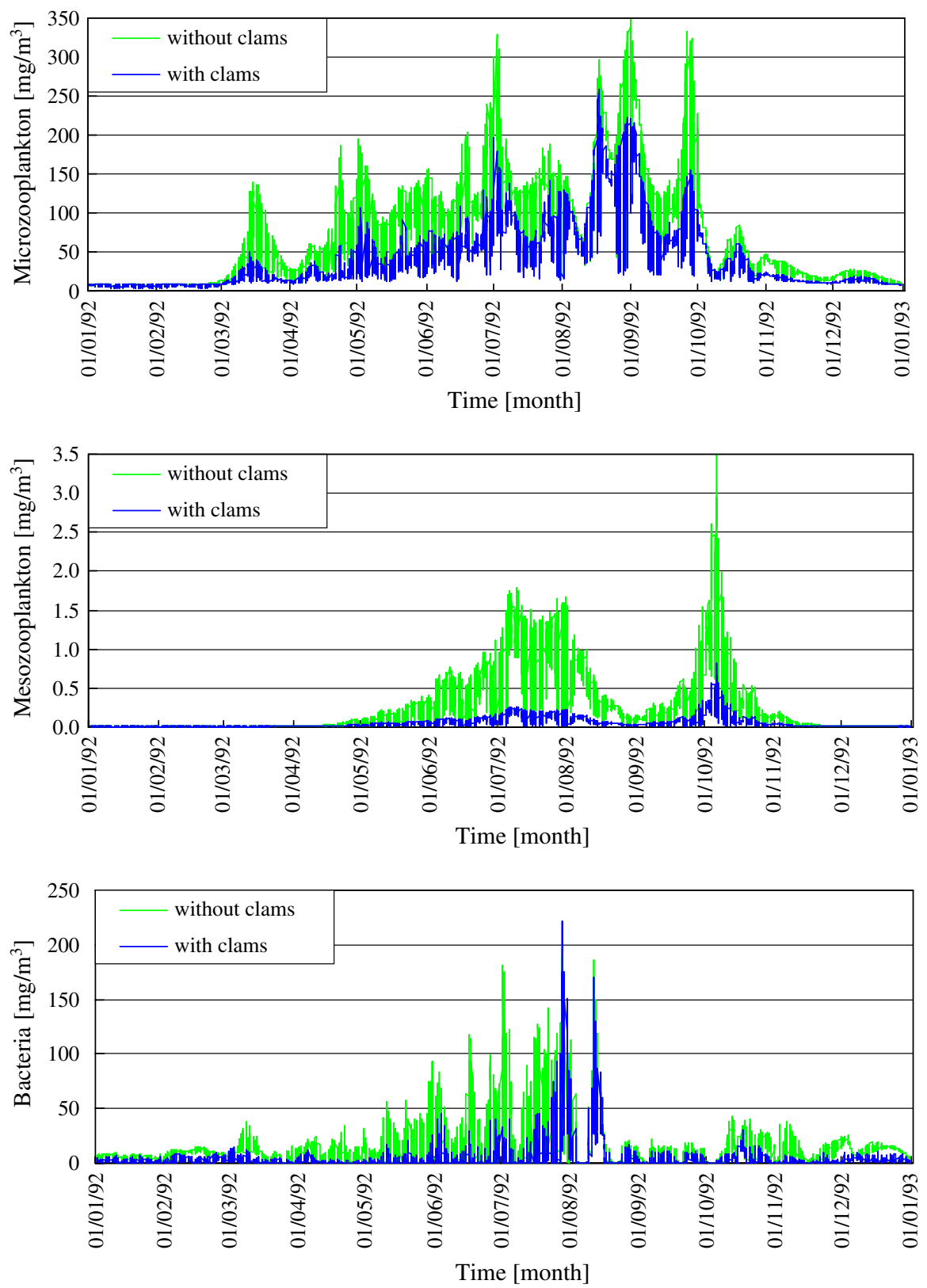

development of a secondary bloom of filamentous macroalgae, e.g. Cladophora sp. (Viaroli et al., 2001, 2006).

The influence of AS on phytoplankton delivery to the lagoon is also shown in Fig. 10, where a clear gradient with decreasing chlorophyll- $a$ concentrations from the AS through the western SG area was attained in August. A similar trend was also evidenced for the secondary lagoon mouth, in the eastern SG side, where a depletion of chlorophyll- $a$ occurred.
This figure is in accordance with the experimental data collected from 1989 to 1992, which highlighted a lagoon zonation with phytoplankton biomass maxima in the western-central area and minima in the southeastern zone (Viaroli et al., 1992; Colombo et al., 1994). The zone of chlorophyll- $a$ depletion coincided with the farming area, supporting the hypothesis that clams controlled suspended particulate matter through their filtration activity (Nizzoli et al., 2007). 

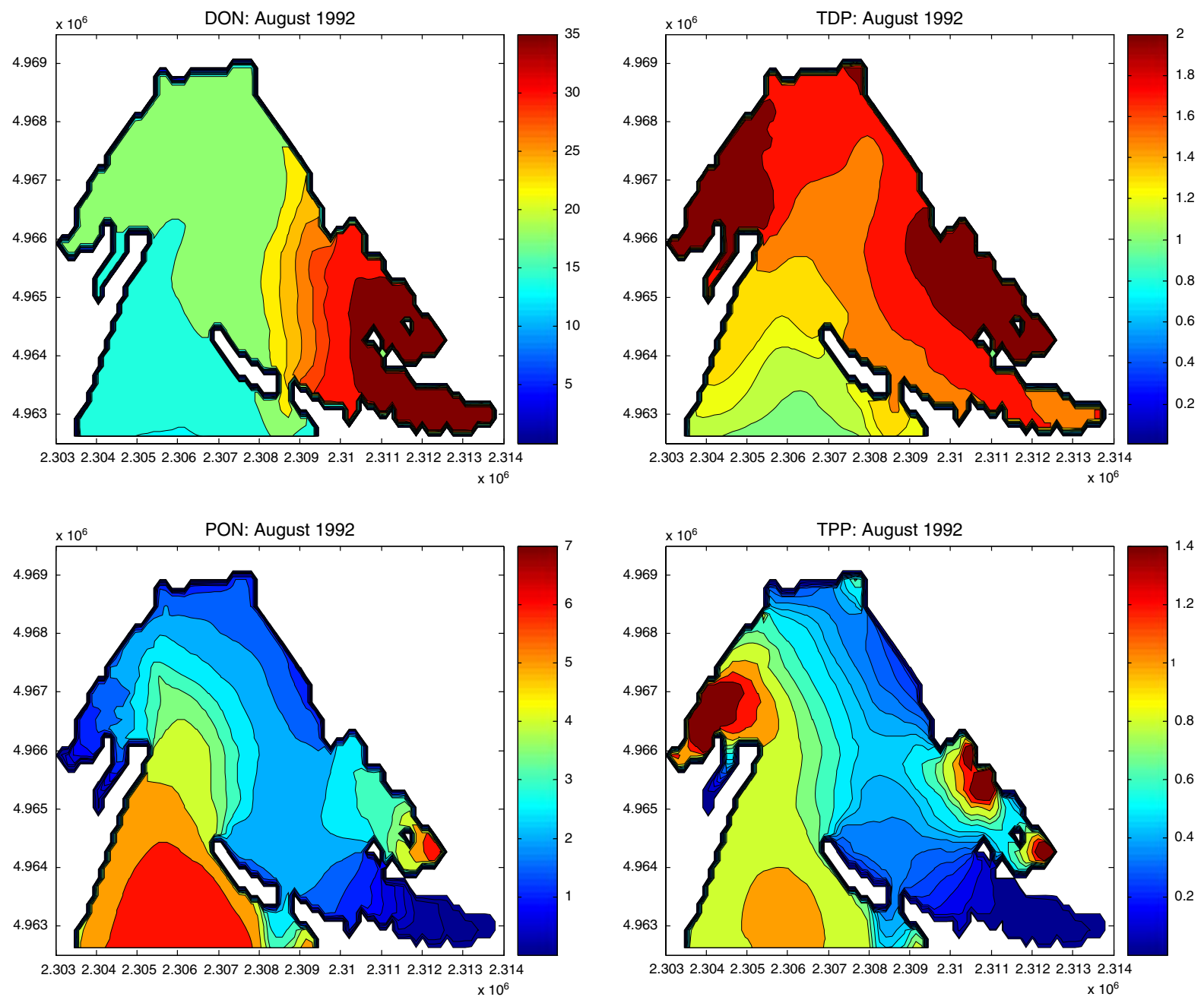

Fig. 8 Spatial surface distribution of DON, PON TDP and TPP concentrations $\left(\mathrm{mmol} \mathrm{m}^{-3}\right)$ in SG including clam farming in the simulation (August 1992)

Fig. 9 Comparison

between numerical results and measured concentrations of chlorophyll- $a$ at the central station in SG

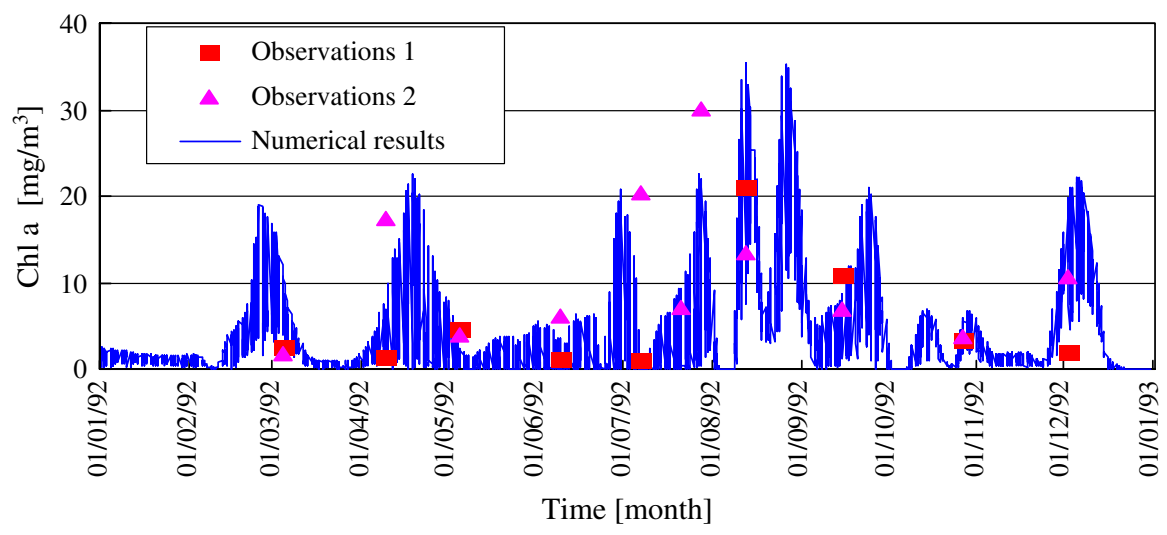


Fig. 10 Spatial surface distribution of chlorophyll$a\left(\mathrm{mg} \mathrm{m}^{-3}\right)$ in SG including clam farming in the simulation (August 1992)

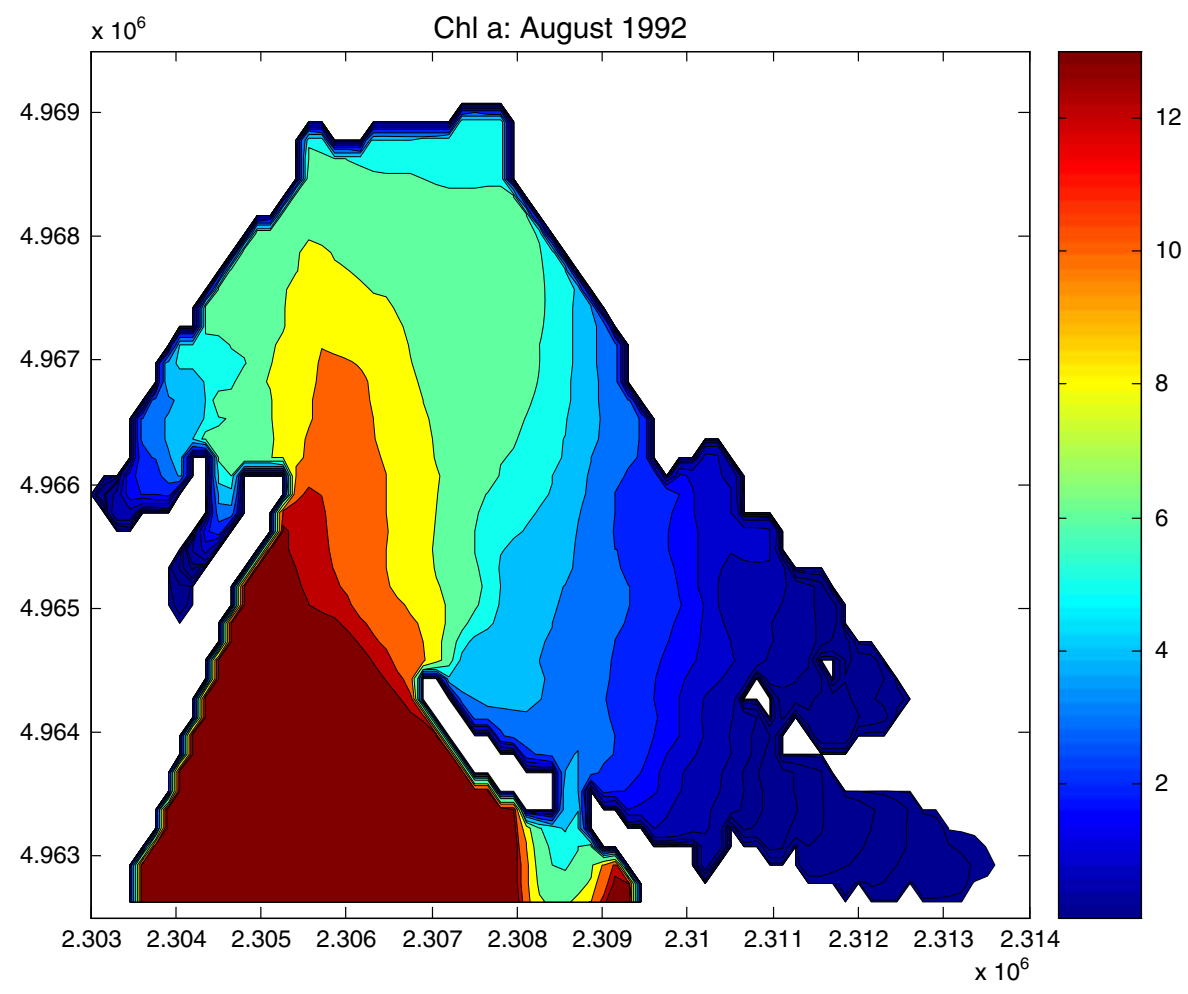

Fig. 11 Comparison of results of the numerical model for Ulva dynamics with filed observations at station close to Goro village in 1992

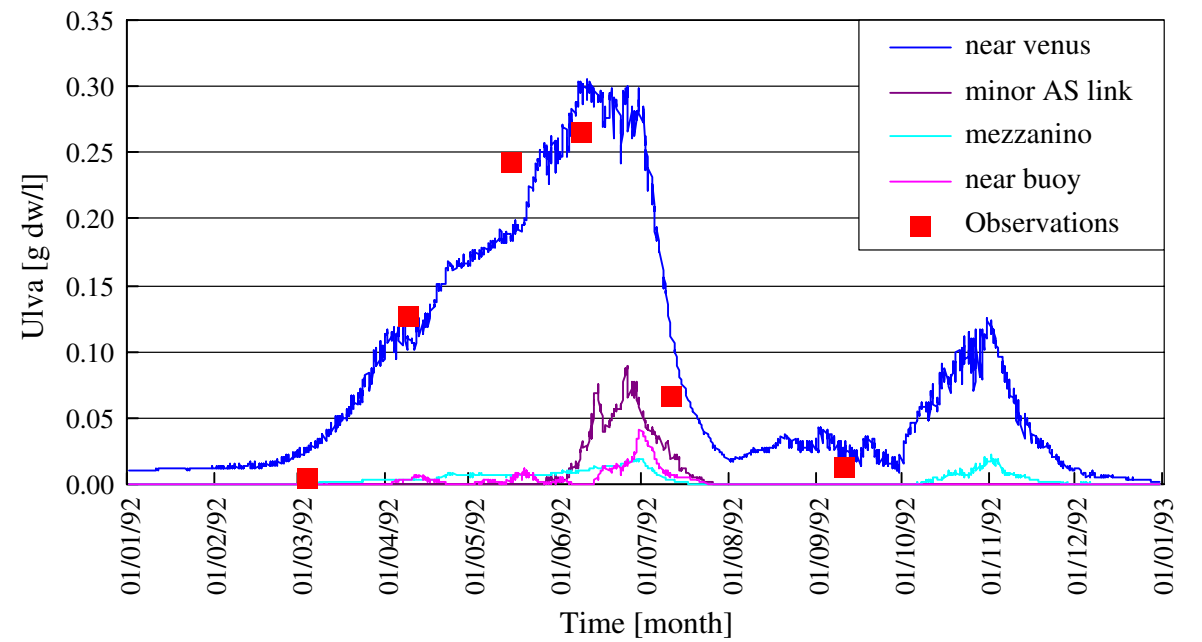

\section{Ulva sp. dynamics}

The simulation exercise evidenced that the decomposition phase influenced the dynamics of dissolved and particulate organic phosphorus and nitrogen, which peaked in mid July (Fig. 6). This pattern was consistent with findings of field experiments performed with benthic chambers within Ulva mats
(Viaroli et al., 1996) as well as with decomposition kinetics in laboratory experiments (Viaroli et al., 1992).

Simulated values of Ulva biomass are reported (Fig. 11) for four stations within the SG, along with experimental data determined at station near to Goro village. As far as the latter station is concerned, in 1992 the model was able to describe the Ulva 
dynamics. Overall, the exponential increase (maximum growth) in spring was followed by a fast decay in July and a secondary peak in November.

The macroalgae spreading within SG and the spatial distribution of Ulva were of great importance in driving the seasonal evolution of the lagoon trophic conditions (Viaroli et al., 2006) that only a 3D model can address. Following experimental observations (Viaroli et al., 1993, 2006), Ulva growth was initialized in two confined parts of the lagoon and then a low drifting with water currents was assumed (Menesguen, 1992). Ulva attained the maximum development in June, when the biomass peak was reached in the eastern sheltered zone (Fig. 12). The width of the macroalgal bed is in agreement with the spatial distribution recorded in a
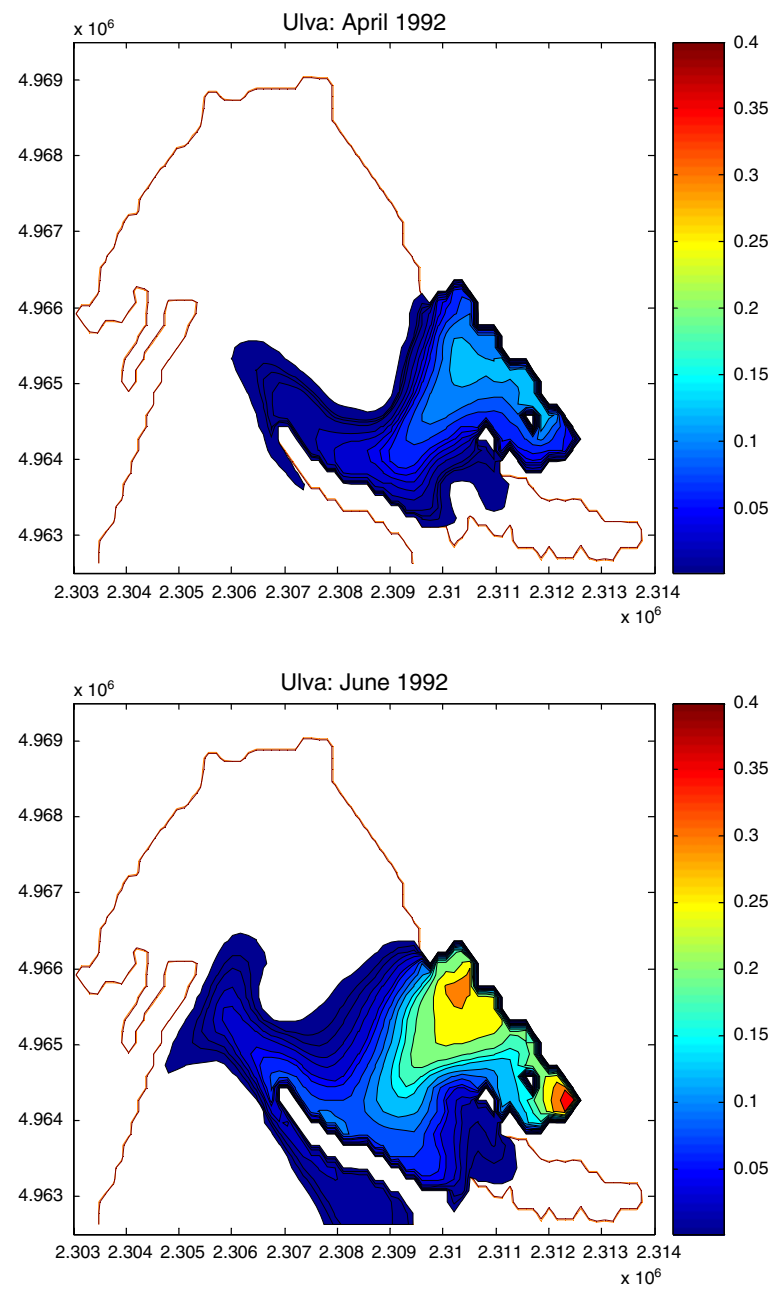

grid of 10 stations within SG in 1991 and 1992 (Viaroli et al., 1993).

\section{Clams farming}

A typical picture of the cumulated clam production through 1 year in a single rearing cell of 2.25 ha at three different locations is presented in Fig. 13. In 1992, the total production estimated with the model was 16,700 tons in an area of 886.5 ha, with an average production of $1.9 \mathrm{~kg} \mathrm{~m}^{-2} \mathrm{y}^{-1}$, a maximum of $3.1 \mathrm{~kg} \mathrm{~m}^{-2} \mathrm{y}^{-1}$ and a minimum of $0.4 \mathrm{~kg} \mathrm{~m}^{-2} \mathrm{y}^{-1}$. The 3D model was a useful tool to assess this aspect. For example, Fig. 13 shows clearly the different dynamic behaviour of productivity in three single rearing cells (2.25 ha) placed at different zones of SG,
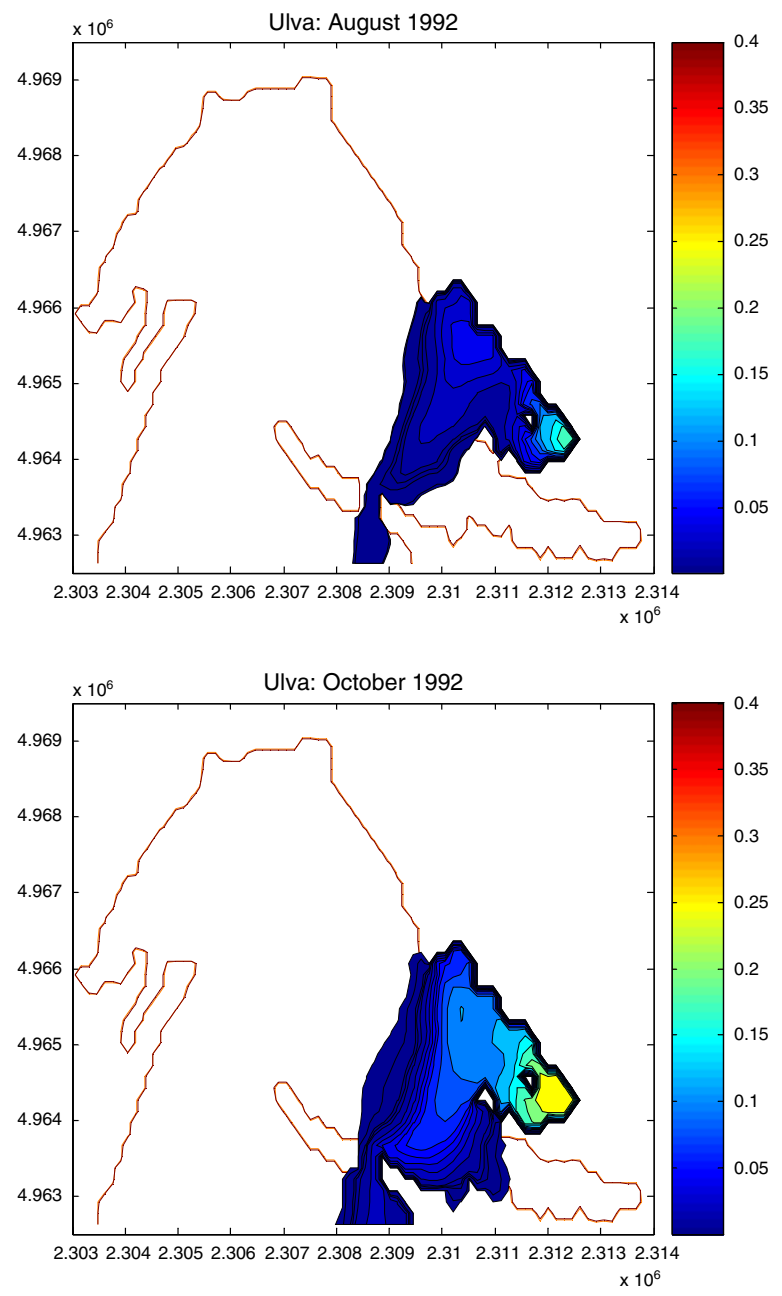

Fig. 12 Spatial surface distribution of Ulva sp. ( $\mathrm{g} \mathrm{m}^{-3}$ as dry weight) in SG from April to October 1992 
Fig. 13 Accumulated production of clams in three single rearing cells (2.25 ha) placed at different zones of SG-near to Observation points 22 and 7 and Buoy station (see Fig. 1)

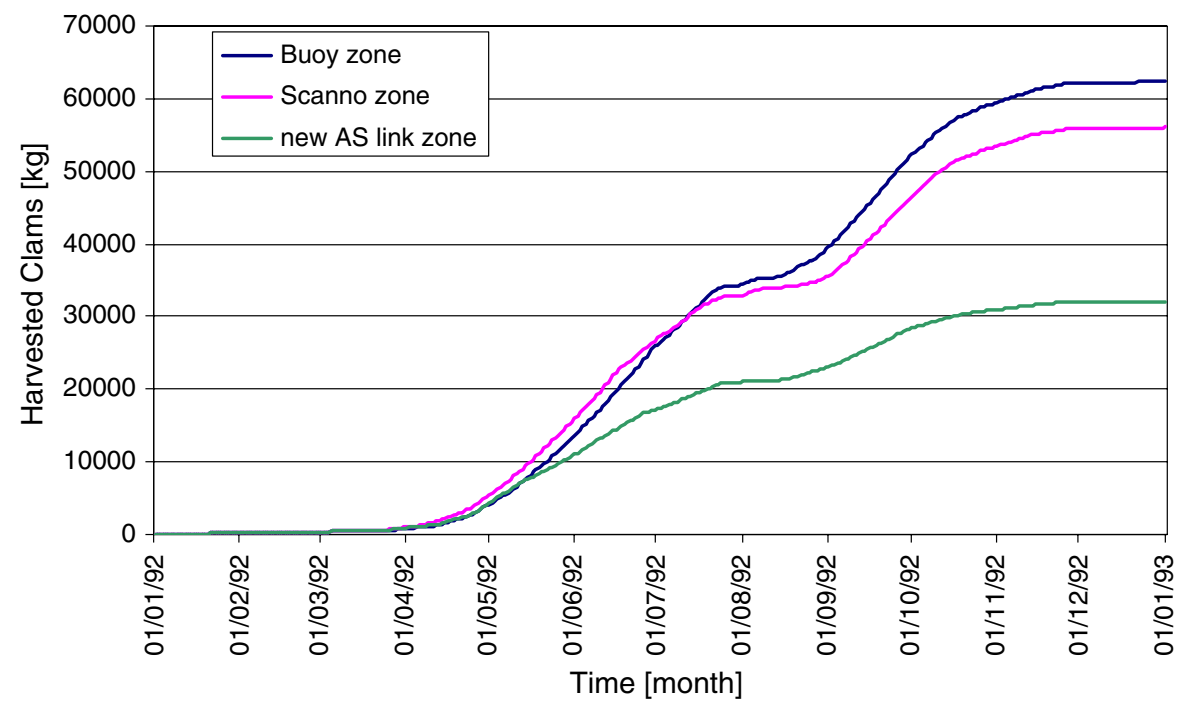

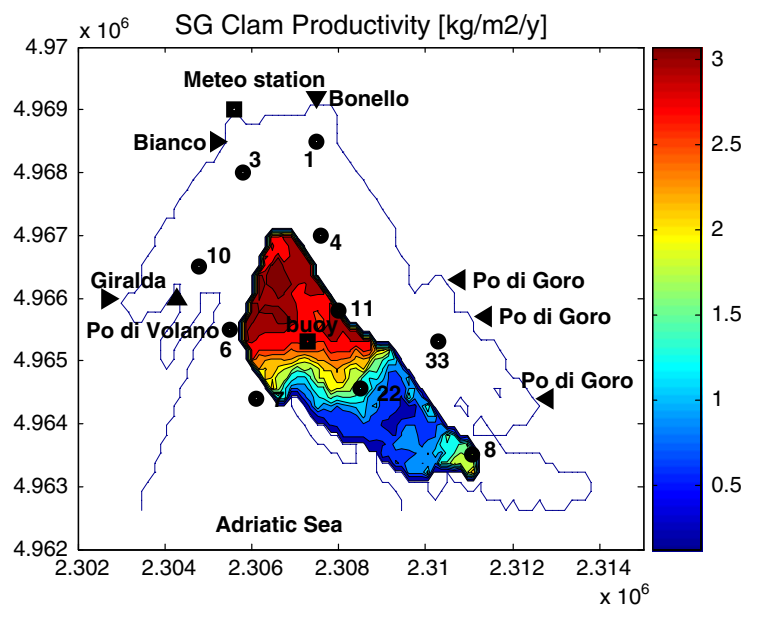

Fig. 14 Simulated annual clam productivity in SG

whereas Fig. 14 shows a productivity map in the clam farming areas of the lagoon. The more productive areas were found in zones near to the lagoon mouths, where higher hydrodynamics and intensive exchange between lagoon and open sea ensured better physical and chemical conditions for clam to grow, namely food abundance, oxygen availability, suitable temperature, salinity, etc. In this case, one should have in mind that the second connection was only open in August 1992. The areas of high productivity are in good agreement with a recent study from Vincenzi et al. (2006), in which a GIS-based habitat suitability model was developed.

\section{Discussion}

A coupled 3D hydrodynamic-biogeochemical model for simulation of coastal lagoon, including clam farming, has been developed and successfully applied in the Sacca di Goro coastal lagoon. The year 1992 was selected for model running since it was one of years with the highest data availability for lagoon, watershed and Adriatic Sea. Furthermore, in 1992 a new connection was opened in the sand barrier separating the lagoon from open sea as a consequence of a strong anoxic crisis which followed a wide macroalgal bloom.

A full 3D hydrodynamic-biogeochemical model is not easy to calibrate and to validate (Pastres et al., 1999; Lancelot et al., 2002). However, each of the sub-models included into the biogeochemical model developed in this study were already validated. For example, the combination of plankton model (Lancelot et al., 1991) and microbial loop model (Billen, 1991) was calibrated on FRONTAL 1986 data for Liguria Sea in Tusseau et al. (1997) and on Black Sea data by Lancelot et al. (2002), as well as the effects of uncertainty of model input was addressed by calculating a confidence interval for model results using Monte-Carlo techniques. Furthermore, the sediment sub-model was calibrated versus field data for Thau lagoon (Mediterranean coast of France) in Chapelle (1995) as well as a similar approach was followed for Ulva sp. with data from Venice lagoon (Solidoro et al., 1997a, b). Finally, the 0D version of 
the integrated biogeochemical model was also intensively examined against observations for nutrients, oxygen, fluxes from sediments, DON, PON, TDP, TPP, Chlorophyll- $a$, zooplankton, bacteria and Ulva sp. in SG for a 10-year period (Zaldívar et al., 2003). Mean nutrient fluxes between the sediments and the water column have been recently validated against experimental data in Giordani et al. (2008).

In the present study the $0 \mathrm{D}$ model version was checked especially for closure of nutrients cycles and sensitivity of optimal and interval temperature parameters for different species. Also, the 0D exercise allowed to determine the most important model parameters, assessing the influence of forcing functions and boundary exchange, and to quantify the influence of the different processes that occur in the lagoon. As a consequence, the results of previous works for calibration and verification of the different sub-models introduced into the present model allows us running it, at least as a first approach, without special effort dedicated to model calibration and verification.

The comparison of numerical results with measured data indicated that the model was able to capture essential temporal dynamics and spatial variability of the Sacca di Goro lagoon. The model was forced to simulate the development of huge amounts of macroalgal biomass which was assumed to fuel both the organic matter pools and the inherent microbial community. Especially, during the bloom formation and after the dystrophic crisis the most part of carbon and nutrients resulted incorporated in the organic pools and the inorganic species were almost negligible (Viaroli et al., 2001, 2006). Experimental data on this subject are scarce, nevertheless it was possible to identify variables for several model compartments, e.g. two state variables concerning DON pools at both high and low biodegradability levels.

Model runs were able to simulate macroalgal blooms which affected the Sacca di Goro lagoon from mid 1980s until 1998. Blooms of green macroalgae, specially of Ulva sp., were the main cause of anoxic crises during late spring and summer. Such crises were responsible for a considerable damage to shellfish farming and to the ecosystem functioning. Usually, the rapid growth and spreading of Ulva sp. in spring were followed by the decomposition of the macroalgal bulk, which lasted from mid June onwards (Viaroli et al., 2001, 2006). The organic matter availability stimulated microbial growth and oxygen depletion, shifting the whole system towards anoxia and anaerobic metabolism, mostly in the bottom water. This process was followed by a peak of soluble reactive phosphorous, and to a lesser extent of ammonium, that were released from both decomposing biomass and anoxic sediments.

The present version of the 3D model was also used for a preliminary estimate of clam productivity, which is an important economic activity both at local and regional levels. The annual production rates simulated with the model were in agreement with the experimental values reported by Castaldelli et al. (1993) and by Nizzoli et al. (2007), as well as they corresponded to the marketable clam production estimated by Ferrara Province for 1992, which was around 15,000 tons. Some preliminary estimates about clam production were also performed with the original discrete stage growth OD model of Zaldívar et al. (2005). Although this model was able to reproduce the mean annual yield for more than a 10 -year period, it was not capable to indicate which zone of the lagoon would be more suitable for clam farming.

As clams feed on suspended particulate matter, they can control phytoplankton, bacterioplankton and, to a certain extent, zooplankton (Sorokin \& Giovanardi, 1995; Nakamura, 2001). Under farming conditions, clam predators are expected to be almost negligible, therefore, energy transfer and biogeochemical cycling are for the most part controlled by clams themselves (Valiela, 1995). Ammonium regeneration can determine a positive feedback, supporting both phytoplankton and Ulva growth (Bartoli et al., 2003). Even though clams are able to exploit phytoplankton, they probably cannot control phytoplankton communities during blooms. This function is normally carried out by zooplankton, whose growth is quickly stimulated by increased phytoplankton availability. The comparison of simulations with and without clams evidenced that zooplankton and bacterial biomass underwent a decrease when clams were present. The temporal patterns of the large-sized zooplankton forms were consistent with observations made in 1988-1989 and from 1992 to 1994, which evidenced a summer peak (Sei et al., 1996). However, field observations evidenced that the zooplankton community was also affected by 
macroalgal blooms, which in turn depressed phytoplankton growth determining a cascade effect through the planktonic food web (Pugnetti et al., 1992; Sei et al., 1996).

Temporal patterns of microbial communities were also consistent with the macroalgal growth, bacteria being fuelled by organic matter and favoured by substratum availability. The biomass peak was attained in August, after the bloom collapse and coinciding with biomass decomposition. As for phytoplankton and zooplankton, the bacterial biomass was controlled by clams, which substantially decreased bacterial density.

The observations as well as the model results showed that the lagoon was a highly heterogeneous system which imposed necessity to reconsider existing sampling strategies, since the time scales involved in some biogeochemical processes were shorter than the typical weekly or monthly interval adopted for sampling in most of the water systems under study. Basically, the bias between monitoring and simulation timing makes difficult to assess the validity of any developed model or to decide the performance of competing modelling tools. Furthermore, a typical problem in modelling coastal marine ecosystems is the extreme parametric sensitivity of models. It is still not clear which part of sensitivity is due to our lack of understanding of the ecological mechanisms that govern marine ecosystems, and which part is inherent to the real system and hence limits our prediction capabilities. This is an important problem that should be considered when using ecological lagoon models as tools for the management support and/or for scenario analysis in order to determine what is the predictability window of our system and how accurate are our forecast capabilities.

Finally, an integration of present 3D hydrodynamic-biogeochemical lagoon model with the model of the lagoon watershed (i.e. the Burana-Volano hydrological system) is presently under development. This will allow a better representation of the forcing functions in terms of the dynamics of nutrient loads to Sacca di Goro.

Acknowledgements We gratefully acknowledge S. Bencivelli and P. Magri from Assessorato Ambiente (Provincia di Ferarra) for their assistance and data provision. We also gratefully acknowledge G. Montanari from ARPA (Agenzia Regionale Prevenzione e Ambiente) Cesenatico for data provision concerning the Adriatic Sea datasets. This research has been partially supported by the EU funded project DITTY (Development of Information Technology Tools for the management of European Southern lagoons under the influence of river-basin runoff, EVK3-CT-2002-00084) in the Energy, Environment and Sustainable Development programme of the European Commission.

Open Access This article is distributed under the terms of the Creative Commons Attribution Noncommercial License which permits any noncommercial use, distribution, and reproduction in any medium, provided the original author(s) and source are credited.

\section{References}

Arhonditis, G., G. Tsirtsis, M. O. Angelidis \& M. Karydis, 2000. Quantification of the effects of nonpoint nutrient sources to coastal marine eutrophication: application to a semi-enclosed gulf in the Mediterranean Sea. Ecological Modelling 129: 209-227.

Bartoli, M., M. Cattadori, G. Giordani \& P. Viaroli, 1996. Benthic oxygen respiration, ammonium and phosphorus regeneration in surficial sediments of the Sacca di Goro (Northern Italy) and two French coastal lagoons: a comparative study. Hydrobiologia 329: 143-159.

Bartoli, M., G. Castaldelli, D. Nizzoli, L. G. Gatti \& P. Viaroli, 2001a. Benthic fluxes of oxygen, ammonium and nitrate and coupled-uncoupled denitrification rates within communities of three different primary producer growth forms. In Faranda, F. M., L. Guglielmo \& G. Spezie (eds), Mediterranean Ecosystems. Structure and Processes. Chapter 29. Springer-Verlag Italia, Milano: 225-233.

Bartoli, M., M. Naldi, D. Nizzoli, V. Roubaix \& P. Viaroli, 2003. Influence of clam farming on macroalgal growth: a microcosm experiment. Chemistry and Ecology 19: 147-160.

Bartoli, M., D. Nizzoli, P. Viaroli, E. Turolla, G. Castaldelli, E. A. Fano \& R. Rossi, 2001b. Impact of Tapes philippinarum farming on nutrient dynamics and benthic respiration in the Sacca di Goro. Hydrobiologia 455: 203-212.

Bencivelli, S., 1998. La Sacca di Goro: La situazione di emergenza dell'estate 1997. In AAVV, Lo stato dell'ambiente nella provincia di Ferrara. Anno 1997. Amministrazione Provinciale di Ferrara. Servizio Ambiente, 61-66.

Billen, G., 1991. Protein degradation in the aquatic environment. In Chrost, R. (ed.), Microbial enzymes in the aquatic environment, Vol. 7. Springer, Berlin: 123-143.

Borum, J., 1996. Shallow waters and land/sea boundaries. In Jorgensen, B. B. \& K. Richardson (eds), Eutrophication in Coastal Marine Ecosystems, Vol. 52. Coastal an Estuarine Studies, American Geophysical Union, 179-203.

Bucci, G., C. Rosini, M. G. Rossetti, G. Tuffanelli, M. R. Verniani \& L. Zampino, 1994. Indagine microbiologica su acque di mare e mitili (Gennaio 1898-Dicembre 1990). In Bencivelli, S., N. Castaldi \& D. Finessi (eds), Sacca di Goro: Studio integrato sull'ecologia. FrancoAngeli, Milano: 165-175. 
Carafa, R., D. Marinov, S. Dueri, J. Wollgast, J. Ligthart, E. Canuti, P. Viaroli \& J. M. Zaldívar, 2006. A 3D hydrodynamic fate and transport model for herbicides in Sacca di Goro coastal lagoon (Northern Adriatic). Marine Pollution Bulletin 52: 1231-1248.

Castaldelli, G., S. Mantovani, D. T. Welsh, R. Rossi, M. Mistri \& E. A. Fano, 2003. Impact of commercial clam harvesting on water column and sediment physicochemical characteristics and macrobenthic community structure in a lagoon (Sacca di Goro) of the Po River Delta. Chemistry and Ecology 19: 161-171.

Castel, J., P. Caumette \& R. Herbert, 1996. Eutrophication gradients in coastal lagoons as exemplified by the Bassin d'Arcachon and Étang du Prévost. In Caumette, P., J. Castel \& R. Herbert (eds), Coastal Lagoon Eutrophication and Anaerobic Processes (C.L.E.AN.). Hydrobiologia, 329, ix-xxviii.

Ceccherelli, V. U., G. C. Reggiani, G. Caramori, V. Giaiani \& C. Corazza, 1994. Le comunità macrobentoniche della Sacca di Goro e gli effetti di disturbo ambientale: Risultate di due anni d'indagine (Dicembre 1987-Dicembre 1989). In Bencivelli, S., N. Castaldi \& D. Finessi (eds), Sacca di Goro: Studio integrato sull'ecologia. FrancoAngeli, Milano: 83-108.

Chapelle, A., 1995. A preliminary model of nutrient cycling in sediments of a Mediterranean lagoon. Ecological Modelling 80: 131-147.

Colombo, G., R. Bisceglia, V. Zaccaria \& V. Gaiani, 1994. Variazioni spaziali e temporali delle caratteristiche fisicochimiche delle acque e della biomassa fitoplantonica della Sacca di Goro nel quadriennio 1988-1991. In Bencivelli, S., N. Castaldi \& D. Finessi (eds), Sacca di Goro: Studio integrato sull'ecologia. FrancoAngeli, Milano: 9-82.

Crossland, C. J., H. H. Kremer, H. J. Lindeboom, J. I. Marshall Crossland \& M. D. A. Le Tissier (eds), 2005. Coastal Fluxes in the Anthropocene. The Land-Ocean Interactions in the Coastal Zone Project of the International Geosphere-Biosphere Programme. Global Change - The IGBP Series no XX. Springer, $232 \mathrm{pp}$

De Wit, R., L. J. Stal, B. A. Lomstein, R. A. Herbert, H. van Gemerden, P. Viaroli, V. U. Ceccherelli, F. RodríguezValera, M. Bartoli, G. Giordani, R. Azzoni, B. Shaub, D. T. Welsh, A. Donnely, A. Cifuentes, J. Anton, K. Finster, L. B. Nielsen, A. G. Underlien Pedersen, A. T. Neubauer, M. A. Colangelo \& S. K. Heijs, 2001. ROBUST: the role of buffering capacities in stabilising coastal lagoon ecosystems. Continental Shelf Research 21: 2021-2041.

Eisenreich, S., 2005. Climate Change and the European Water Dimension. European Communities, report n. EUR 21553 EN. 253 pp

Giordani, G., M. Austoni, J. M. Zaldivar, D. P. Swaney \& P. Viaroli, 2008. Modelling ecosystem functions and properties at different time and spatial scales in shallow coastal lagoons: an application of the LOICZ biogeochemical model. Estuarine and Coastal Shelf Science 77: 264-277.

Hemminga, M. A., 1998. The root/rhyzome system of seagrasse: an asset and a burden. Journal of Sea Research 39: 183-196.

Herut, B. \& M. Krom, 1996. Atmospheric input of nutrients and dust to the SE Mediterranean. In Guerzoni, S. \& R.
Chester (eds), The Impact of Desert Dust Across the Mediterranean. Kluwer, Dordrecht: 349-358.

Kjerfve, B., 1994. Coastal Lagoon Processes. Elsevier, Amsterdan, $577 \mathrm{pp}$

Lancelot, C., D. Le Roy \& G. Billen (eds), 1991. The Dynamics of Phaeocystis Blooms in Nutrient Enriched Coastal Zones of the Channel and the North Sea. 3rd annual progress report.

Lancelot, C., J. Staneva, D. Van Eeckhout, J. M. Beckers \& E. Stanev, 2002. Modelling the Danube-influenced northwestern continental shelf of the Black Sea. II. Ecosystem response to changes in nutrient delivery by the Danube river after its damming in 1972. Estuarine and Coastal Shelf Science 54: 473-499.

Luyten, P. J., J. E. Jones \& R. Proctor, 2003. A numerical study of the long and short term temperature variability and thermal circulation in the North Sea. Journal of Physical Oceanography 33: 37-56.

Luyten, P. J., J. E. Jones, R. Proctor, A. Tabor, P. Tett \& K. Wild-Allen, 1999. COHERENS - A Coupled Hydrodynamical-Ecological Model for Regional and Shelf Seas: User Documentation. MUMM Report, Management Unit of the Mathematical Models of the North Sea, $911 \mathrm{pp}$.

Marinov, D., L. Galbiati, G. Giordani, P. Viaroli, A. Norro, S. Bencivelli \& J. M. Zaldívar, 2007. An integrated modelling approach for the management of clam farming in coastal lagoons. Aquaculture 269: 306-320.

Marinov, D., A. Norro \& J. M. Zaldívar, 2006. Application of COHERENS model for hydrodynamic investigation of Sacca di Goro coastal lagoon (Italian Adriatic Sea shore). Ecological Modelling 193: 52-68.

Medinets, M., 1996. Shipboard derived concentrations of sulphur and nitrogen compounds and trace metals in the Mediterranean aerosol. In Guerzoni, S. \& R. Chester (eds), The Impact of Desert Dust Across the Mediterranean. Kluwer, Dordrecht: 359-368.

Melià, P., D. Nizzoli, M. Bartoli, M. Naldi, M. Gatto \& P. Viaroli, 2003. Assessing the potential impact of clam rearing in dystrophic lagoons: an integrated oxygen balance. Chemistry and Ecology 19: 129-146.

Menesguen, A., 1992. Modelling coastal euthrophication: the case of French Ulva mass blooms. Science of the Total Environment, Supplement 1992: 979-992.

Nakamura, Y., 2001. Filtration rates of the Manila clam, Ruditapes philippinarum: dependence on prey items including bacteria and picocyanobacteria. Journal of Experimental Marine Biology and Ecology 266: 181-192.

Nizzoli, D., M. Bartoli \& P. Viaroli, 2007. Oxygen and ammonium dynamics during a farming cycle of the bivalve Tapes philippinarum. Hydrobiologia 587: 25-36.

O’Kane, J. P., M. Suppo, E. Todini \& J. Turner, 1992. Physical intervention in the lagoon Sacca di Goro. An examination using a 3-D numerical model. Science of the Total Environment, Supplement 1992: 489-509.

Pastres, R., K. Chan, C. Solidoro \& C. Dejak, 1999. Global sensitivity analysis of shallow-water 3-D eutrophication model. Computer Physics Communications 117: 62-74.

Provini, A. \& A. Binelli, 2006. Environmental quality of the Po River Delta. In Wangersky, P. J. (ed.), The Handbook of Environmental Chemistry, Estuaries, Vol. 5/H. SpringerVerlag, Berlin: 175-195. 
Pugnetti, A., P. Viaroli \& I. Ferrari, 1992. Process leading to dystrophy in a Po River Delta lagoon (Sacca di Goro): phytoplankton-macroalgae interactions. Science of the Total Environment, Supplement 1992: 445-456.

Schramm, W., \& P. H. Nienhuis, 1996. Marine Benthic Vegetation. Recent Changes and the Effects of Eutrophication. Springer, New York, 470 pp

Sei, S., G. Rossetti, F. Villa \& I. Ferrari, 1996. Zooplankton variability related to environmental changes in a eutrophic coastal lagoon in the Po Delta. Hydrobiologia 329: 45-55.

Simeoni, U., G. Fontolan \& P. Ciavola, 2000. Morfodinamica delle bocche lagunari della Sacca di Goro. Studi Costieri 2: $123-138$.

Solidoro, C., V. E. Brando, C. Dejak, D. Franco, R. Pastres \& G. Pecenik, 1997a. Long term simulations of population dynamics of Ulva rigida in the lagoon of Venice. Ecological Modelling 102: 259-272.

Solidoro, C., R. Pastres, D. Melaku Canu, M. Pellizzato \& R. Rossi, 2000. Modelling the growth of Tapes philippinarum in Northern Adriatic lagoons. Marine Ecology Progress Series 199: 137-148.

Solidoro, C., G. Pecenik, R. Pastres, D. Franco \& C. Dejak, 1997b. Modelling macroalgae (Ulva rigida) in the Venice lagoon: model structure identification and first parameters estimation. Ecological Modelling 94: 191-206.

Sorokin, Y. I. \& O. Giovanardi, 1995. Trophic characteristics of the Manila Clam (Tapes philippinarum Adams and Reeve). ICES Journal of Marine Sciences 52: 853-862.

Tusseau, M.-H., C. Lancelot, J. M. Martin \& B. Tassin, 1997. 1-D coupled physical-biological model of the northwestern Mediterranean Sea. Deep-Sea Research II 44: 851880.

Tusseau, M.-H., L. Mortier \& C. Herbaut, 1998. Modeling nitrate fluxes in an open coastal environment (Gulf of Lions): transport versus biogeochemical processes. Journal of Geophysical Research 1003: 7693-7708.

Valiela, I., 1995. Marine Ecological Processes, 2nd edn. Sprinter-Verlag, New York, 686 pp

Viaroli, P., R. Azzoni, M. Bartoli, G. Giordani \& L. Tajé, 2001. Evolution of the trophic conditions and dystrophic outbreaks in the Sacca di Goro lagoon (Northern Adriatic
Sea). In Faranda, F. M., L. Guglielmo \& G. Spezie (eds), Structure and Processes in the Mediterranean Ecosystems. Chapter 59. Springer-Verlag, Milano: 443-451.

Viaroli, P., M. Bartoli, C. Bandavalli, R. R. Christian, G. Giordani \& M. Naldi, 1996. Macrophyte communities and their impact on benthic fluxes of oxygen, sulphide and nutrients in shallow eutrophic environments. Hydrobiologia 329: 105-119.

Viaroli, P., G. Giordani, M. Bartoli, M. Naldi, R. Azzoni, D. Nizzoli, I. Ferrari, J. M. Zaldívar, S. Bencivelli, G. Castaldelli \& E. A. Fano, 2006. The Sacca di Goro and an arm of the Po river. In Wangersky, P. J. (ed.), The Handbook of Environmental Chemistry, Estuaries, Vol. 5/ H. Springer-Verlag, Berlin: 197-232.

Viaroli, P., M. Naldi, R. R. Christian \& I. Fumagalli, 1993. The role of macroalgae and detritus in the nutrient cycles in a shallow-water dystrophic lagoon. Verhandlungen Internationale Vereinigung Limnologie 25: 1048-1051.

Viaroli, P., A. Pugnetti \& I. Ferrari, 1992. Ulva rigida growth and decomposition processes and related effects on nitrogen and phosphorus cycles in a coastal lagoon (Sacca di Goro, Po River Delta). In Colombo, G., I. Ferrari, V. U. Ceccherelli \& R. Rossi (eds), Marine Eutrophication and Population Dynamics. Olsen \& Olsen, Fredensborg: $77-84$.

Vincenzi, S., G. Caramori, R. Rossi \& G. A. De Leo, 2006. A GIS-based habitat suitability model for commercial yield estimation of Tapes philippinarum in a Mediterranean coastal lagoon (Sacca di Goro, Italy). Ecological Modelling 193: 90-104.

Zaldívar, J. M., M. Austoni, M. Plus, G. A. De Leo, G. Giordani \& P. Viaroli, 2005. Ecosystem health assessment and bioeconomic analysis in coastal lagoons. In Jørgensen, S. E., F.-L. Xu \& R. Costanza (eds), Handbook of Ecological Indicators for Assessment of Ecosystem Health. CRC Press, Boca Raton, FL: 163-184.

Zaldívar, J. M., E. Cattaneo, M. Plus, C. N. Murray, G. Giordani \& P. Viaroli, 2003. Long-term simulation of main biogeochemical events in a coastal lagoon: Sacca di Goro (Northern Adriatic Coast, Italy). Continental Shelf Research 23: 1847-1875. 